\title{
Sources of Consumers Awareness toward Green Products and Its Impact on Purchasing Decision in Bangladesh
}

\author{
Md. Zillur Rahman Siddique ${ }^{1} \&$ Afzal Hossain ${ }^{2}$ \\ ${ }^{1}$ Assistant Professor, Department of Marketing, Comilla University, Comilla, Bangladesh \\ ${ }^{2}$ MBA Student, Department of Marketing, Comilla University, Comilla, Bangladesh \\ Correspondence: Md. Zillur Rahman Siddique, Department of Marketing, Comilla University, Comilla, \\ Bangladesh. E-mail: emon.mkt05@gmail.com
}

Received: February 27, 2018

doi:10.5539/jsd.v11n3p9

\author{
Accepted: March 21, $2018 \quad$ Online Published: May 18, 2018 \\ URL: https://doi.org/10.5539/jsd.v11n3p9
}

\begin{abstract}
Consumers' green products awareness is significant in indicating the way of the green products buying decision. This study aims to investigate the sources of consumers' awareness toward green products and its impact on purchasing decision. The data is collected from 300 respondents by survey method through a structured questionnaire with five-point Likert scales \& multiple items. Convenience and judgmental sampling method are used. Data are analysed using frequency analysis, mean, standard deviation and regression analysis. The study has found that promotional activities on eco-friendly products and reference groups significantly influence consumers green products awareness. Majority of the respondents are aware of green products. This study also reveals that green products awareness as the critical factor, which significantly affects consumers green purchasing decision. This paper can contribute to this green awareness issues. The company can be benefited knowing sources of green products awareness. Those it can aid green awareness development along with green products offer to consumers.
\end{abstract}

Keywords: green product, awareness, purchase decision, sources of awareness, impacts on purchase

\section{Introduction}

The sum entire of all ambience of living creatures, together with natural forces and other breathing things, which offer conditions for upliftment and growth, are in danger and damage (Business Dictionary). The actors and forces outside marketing that influence marketing management's ability to create and keep up successful relationships with target customers and environmental issues also accelerate marketing activities as environmental marketing activities (Kotlar \& Armstrong, 2009). Environmental issues like depletion of natural resources, changing the weather, global warming is most talked about topics now a day. This problem may directly or obliquely influence the way one treats, specifically while making a purchase decision. The voracity of people and intention to acquire maximal with minimal caused in a tarnishing the essential supporting structures of life such as land, water and air (Smith, 2009). In this global warming situation, green products can reduce the environmental deterioration. A green product is can be expressed as eco-friendly, non-toxic recyclable, yielded by organic constituents and substance having a positive effect on the human being. The customer always favours to buy a green product from popular and recognized firms (Suki, 2013). Consumers of green products cut down to purchase those products which are detrimental for people and pollute the atmosphere during the production, use or dispose of those goods. Businesses are applying different exceptional promotional campaigns and tactics to develop the green product. Green products convey the information to the consumer about the eco-benefits about using product and these green products also to aid to inspire and fetch the alteration in consumer buying behaviour positively (Carlson \& George, 1995). As consumers prefer green product widely, green products are becoming market leader day by day. Thus, it is raising the demand for the eco-friendly product around the world (Wahid \& Rahbor, 2011). The movement for green is observed to be growth at a radical speed all over the world. Consumers are also showing right activities and responsive behaviour regarding environmental movement. Because of the changes in consumer behaviour due to environmental awareness and intentions to do better for ecology, more and more eco-friendly products are launching to market (Shruti, 2014). Green marketing (Offering Green products) concept incorporates a wide range of activities for establishing the consumer rights, saving the environment and meeting the consumer needs or wants and preferences. In the present world, consumers are more aware of their safety of life and want everything would 
be environment-friendly products and making the green world. Green marketing struggles with fraudulent practices, grey marketing, food contamination and protect consumers from impudence businessman. The green marketing concept is already activated all over the world. Green awareness has changed the role of consumers to demonstrate their accountability to save the world before buying activities (Cherian \& Jacob, 2012). Consumers have a tendency to assess the features of a specific green product sensibly and regard its influence on the environment (Gan et al., 2008; Prakash, 2002). Green awareness appreciates the products which are less detrimental to the environment, all living creatures, and most prominently, biodegradable (Borin et al., 2013; Tiwari et al., 2011). Many companies take support to develop an environment-friendly product to fascinate the customer. While some apply green awareness strategies for developing new products and can increase the volume of sales successfully by adopting green marketing activities (Raska, 2012). Green consumers are aware about environmental pollution; therefore, they confirm impacts of consuming product to environmental pollution and try to maintain it at zero level (Tiwari et al., 2011). Meanwhile, consumers give importance of environmental products to save the environment, the consumers then transform their concern through buying actions and purchasing the eco-friendly products (Moser, 2015; Young et al., 2010). Green consumers are willing to pay premium price because they know that this additional payment will bring green benefits for themselves and society. Besides, green products give an impress of being coherent to a progressive environmental regime which prepares us always with positive environmental mind (Florenthal \& Arling, 2011; Young et al., 2010). Environmental damage can be reduced by designing, consuming, and labelling eco-friendly products and for this consumer awareness is essential to be successive. Green products consumers become more careful about ambience preservation (Delafrooz et al., 2014).

Bangladeshi consumers must adopt environmentally sound behaviours to keep up the clean environment. By location, Bangladesh falls in the coastal region. Bangladesh is going to be worst sufferers due to the impact of quick climate change throughout the globe. The coastal areas of Bangladesh are different from rest of the country because of different socio-political consequences and their unique geophysical characteristics that often limit people's ingress to syntactic resources and perpetuate risk and vulnerabilities. Bangladesh's coast is the most significant victim of natural disasters and profoundly affected by climate change with problems including soil erosion, flooding and cyclones salinity and waterlogging. Therefore, this study aims to study sources of green product awareness and its' impact on purchasing decision in Bangladesh.

Achieving the objective, this paper is allocated into the following segments. Firstly, the literature review and conceptual framework are provided based on past literature. Secondly, methodologies are explained which are applied on the study. Next part of the study is presented with the results and discussion. After that, the conclusions and implications are described for the interested parties like a business, researcher, etc. Finally, the limitations and further research scope are represented.

\section{Literature Review and Conceptual Framework}

According to American Marketing Association (2017) have defined green marketing based on impact of marketing activities on pollutions, energy resources and non-energy resource consumption where relationship is presented in terms of positivity and negativity of those factors. Polonsky (1994) stated that environmental marketing includes a broader array of organizational actions such as product adjustment, variations to the manufacture procedure, delivery change and more and to satisfy human needs or wants, all activities consist green or environmental marketing. And it is designed to create and facilitate an interchange intended so that the fulfilment of these needs and wants will happen with least harmful effect on the nature.Environmental sustainability is defined as a green marketing approach that involves developing strategies that keep up the environment in balance along with profits for the company. It is a significant but difficult social target, and many companies are taking at least some actions to save and preserve the environment (Kotler \& Armstrong, 2009). People believe that natural resources are favourable and less damaging to the environment (Schlegemich et al., 1996). A green product is referred as naturally produce, bio-degradable non-toxic, non-experimental on creatures, contamination free, nominally packed with natural and permitted constituents (Ottman, 1993). Environmentally friendly activities deal, for instance, with better pollution controls, energy-efficient operations, and recycled materials (Kotler \& Armstrong, 2009). People who are concerns about environmental safety, follow green buying behaviour and consume green product are considered as green consumer (Yazdanifard \& Yan, 2014). Consumers whose buying behaviour is influenced by environmental concerns will be considered as green consumers (Shrum et al., 1995). Buying green products, insulating home with new equipment, buying environment-friendly and energy-efficient cars are green purchase behaviours (Shabani et al., 2013). Consumers who concern more about the environmental issues have the more possibility to purchase green products (Yeonshin \& Sejung, 2005). Consumers green buying process refers to the self-regulating relationship between consumption of green product deriving from needs, wants and choices. 
Effects of cultures, conditions and demography of people have influences on those needs (Kotler et al., 2009). Willingness to pay more for eco-friendly products does not always indicate green buying behaviour, some green buyers may be price sensitive (Mandese, 1991). According to Barr \& Gilg (2006), environment protectionists are highly concern about environmental issues and play significant role for the betterment of environment where it is possible. Negative insights are possible to reduce if the benefits of green product can be communicated through the package or through media advertisement (Luchs et al., 2010). Population explosion and excess consumption of resources have led environment more polluted for which awareness among green consumers raise. So the industries face the pressure to follow environmental ethics in manufacturing process. The claim for green product and green concepts begin to rise when environmental awareness, governing pressure for eco-technology in manufacturing and public health and safety concerns start to increase among people (Srinivas, 2015). Researchers and marketing experts have presented different concepts to identify patterns of green buying behaviour. Those buying behaviour specifies decision regarding when and where to purchase the green products. People may adopt distinct principles to assess the green product in terms of their need fulfilment by considering types of buying and anticipation of performance (Blackwell et al., 2006).Consumers who consider the ecological effect on their consumption pattern and ready to alter their buying actions is recognised as green consumers (Florenthal \& Arling, 2011; Luzio \& Lemke, 2013; Ritter et al., 2015; Tiwari et al., 2011). Green marketing research is also considering green buying decision as vital issue to explore. The green buying behaviourcan be described as interest to favour green corporations (Laroche et al., 2001), accomplishment of the buying actions (Sharma, 2010), implementing a ecological usage outline (Young et al., 2010) and inclination to pay extra currency to purchase eco-friendly offers (Hasan \& Ali, 2015; Laroche et al., 2001).

Many studies and surveys which look into the consumers' awareness cover on diverse issues and area and examine the aspects affecting the awareness of the green product towards green products buying decision. Rather \& Rajendran (2014) Studied on consumer awareness of green products and its impact on green buying behaviour in Jammu \& Kashmir. The study found the level of awareness and buying behaviour. But this survey did not take into account sources of consumer's awareness of green products. Desai (2015) researched on consumer awareness towards environmental-friendly buildings in Pune City. The research found that most of the respondents agreed that eco-friendly buildings are durable and they are made of quality construction materials. Most of the respondents were considering that green create buildings were not easy to keep up, and such buildings are constructed with recycled materials. But it did not show impacts of awareness in a purchase decision. Suki (2013) worked on green awareness and its relationship with consumers' purchasing decision in Malaysia. The study found price information and brand image significantly affects green buying decision. Young people were more concern and females were deemed as part of rising consumer group in Malaysia. But the study did not take into account environmental concern for purchasing choice of green products and it was conducted in Malaysia, not in Bangladesh. Kumar et al. (2012) studied perception along with awareness of young generation towards green products in India. The research found that majority of the respondents knows the green products where men were more conscious of green products. It also concluded that people believe in better quality of green product and considered it as worthy for environmental betterment. But it had surveyed on only youngsters in India not all classes.

Demographic profile is the key concern of researchers to investigate through their study in environmental marketing field. But factors such as environmental concern, knowledge, eco-friendly products, social media, promotional activities etc. can be influential on eco-friendly products. Again a significant literature gap has flowed in Bangladesh perspective by not evaluating any prognostic relationships that may be aware toward green products. The past researchers have not high lightened the predictive relationship environmental concern, knowledge, eco-friendly products, social media, promotional activities on eco-friendly products and reference groups with green products awareness in Bangladesh context. The research purpose is to examine the sources of consumer's awareness of green products and its impact on purchasing decision in Bangladesh. Therefore the study will measure green products awareness creation regarding environmental concern, knowledge, eco-friendly products, social media, promotional activities on eco-friendly products and reference groups.

\subsection{Conceptual Framework}

Consumer prefers those green products that are associated with the environment. Some studies have indicated that assessment of environmental concern are made by product features, the exactness of green product promise to perform, information on the products and its facilities (Forkink, 2010; Luchs et al., 2010). Consumers are worried about the environment which arises from their interest in ecological balance and problem reducing the tendency of consumers. Besides, consumers are more worried about the environment (Murphy et al., 1978). Thus, it is expected that: 
H1: There is a significant relationship between consumers' environmental concern and green products awareness.

Awareness and knowledge play effective role in different types of consumer behaviour (McEachern \& Warnaby, 2008; Hartlieb \& Jones, 2009; Donoghue \& De Klerk, 2009; Chartrand 2005 and Dommeyer \& Gross, 2003). Hartlieb \& Jones (2009) explains the significance of moral labelling for civilising green products awareness role. Eco-packaging helps to build positive image and judgement of consumers. Thus it creates awareness about green products by enhancing knowledge of different critical aspects and also influences consumers' decisions or behaviours. Knowledge can be related to awareness and effect consumer purchasing choices or movements (McEarchern \& Warnaby, 2008). According to McEarchern \& Warnaby (2008), knowledge can be segmented into system knowledge, action-related knowledge, and useful knowledge and all of them provide guidelines for buying decision-making. Thus, it is expected that:

$\mathrm{H} 2$ : There is a significant relationship between knowledge and green products awareness.

Consumer prefers to buy an environment-friendly product from popular and renowned firms (Suki, 2013). Eco-friendly products change the thinking of buying decisions. Positive thinking is established on the mind of people by eco-friendly products (Suki, 20013). Benefits of green product are achieved in different ways: positive personal value, sign of less environmental pollutions and allow making profit. These consumers support the making the profit of those green product. Green marketing can be key strategies to appeal consumer and modify buying behaviour because of environmentalism. Consumption experience can influence behaviour intensions such as knowledge, awareness etc. (Triantafillidou \& Siomkos, 2014). Therefore, becoming more and more familiar with green products could influence awareness toward green products among consumers. Thus, it is expected that:

H3: There is a significant relationship between eco-friendly products and green products awareness.

Mayfield (2008) explains that social media is online or electronic media which opportunities involvement, openness, preservation, community, and connectedness amongst online users. It can be considered as a means for customers to become familiar with the green products, and thus it will develop awareness concerning green product (Macdonald \& Sharp, 2003). Mohammadian \& Mohammadreza (2012) have found strong relationship between social media and generation of green consciousness. Thus, it is expected that:

H4: There is a significant relationship between social media and green products awareness

Green advertising communicates benefits of using green products such as less resource and energy for manufacturing products, sustainable sources, lee harmful for environment and society etc. (Chang, 2011). Those massages impact on consumers' awareness and motivate to buy green products. Ginsberg \& Bloom (2004) have observed that advertisement and package provide information such as environmental safety, recyclability etc. affect positive intensions to purchase green products in America. Thus, it is expected that:

H5: There is a significant relationship between promotional activities on eco-friendly products and green products awareness.

According to Solomon (2006), the reference group can be defined as those people whose attitudes or principles are followed by others and therefore sometimes it influences on other purchasing behaviour. People prefer to follow their reference group's values, norms, attitudes or beliefs and try to adopt those on their own as a guide for awareness and behaviour (Mowen \& Minor, 2000). Reference groups can enforce several kinds of influence on people: their behaviour and attitude can be transformed to its followers, through customs of reference group followers need may generate etc. (Mowen \& Minor, 2000). Influence of reference group is also identified to discuss attitude-behaviour in ecological consumerism using social dilemma theory to find variance between green and non-green buyers (Gupta \& Ogden, 2009). Thus, it is expected that:

H6: There is a significant relationship between reference groups and green products awareness.

Green products awareness refers to the ability of consumer to identify the product with green recognition and recall. Green products awareness can benefit businesses to launch the new green product and progress sales of current products (Markwick \& Fill, 1997). Unfamiliarity with the green product may cause less interested to purchase an eco-friendly product (Glegg et al., 2005). Firms which can generate awareness and give more attentive on the green product will affect purchasing decisions of their consumers. People pay attentions for those companies who can aware environmental benefits of their green products. Moreover, changes of buying behaviours are also occurred because of green product awareness (Ottman, 1993). Thus, it is expected that:

H7: There is a significant relationship between green products awareness and green purchase decision. 


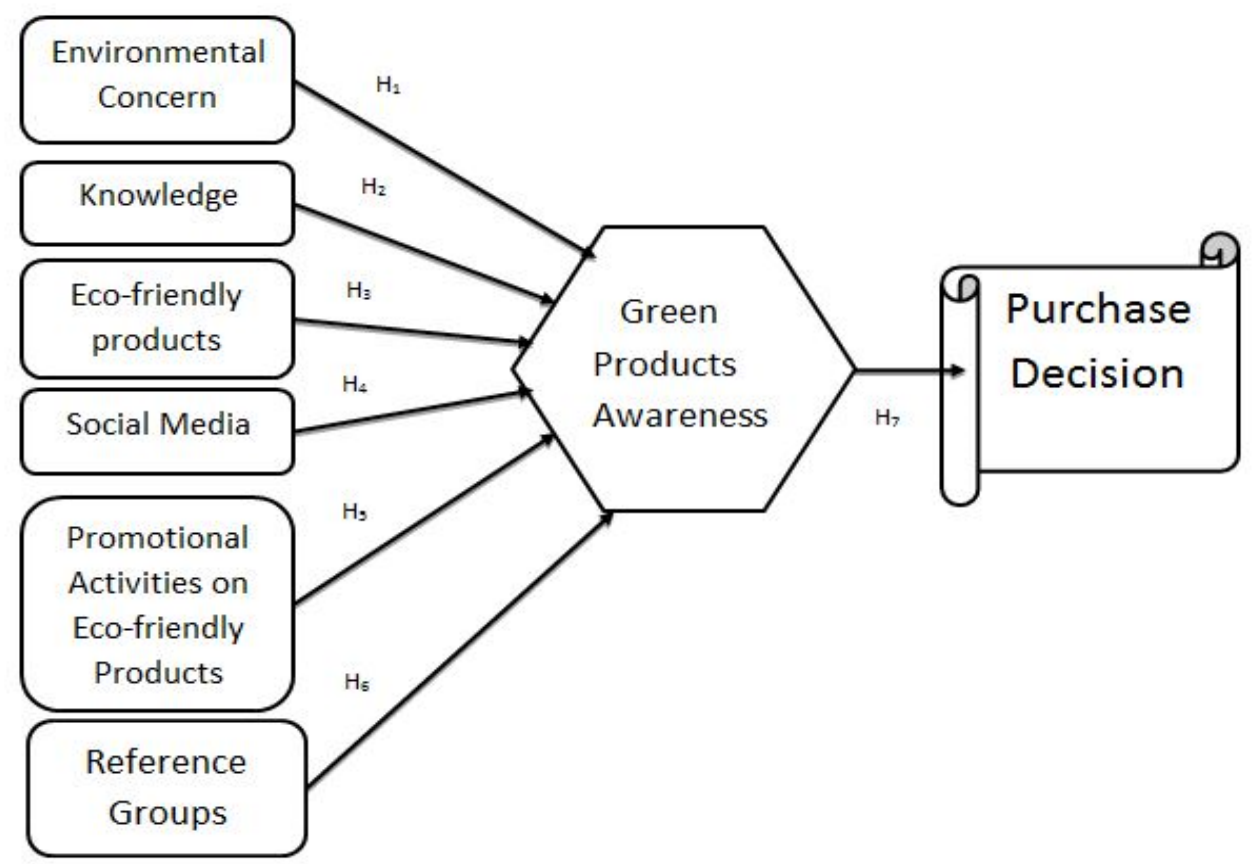

Figure-1: Proposed Research Model

Figure 1. Proposed research model

\section{Research Methodology}

This study is quantitative. For collecting primary data, the personal interview has been conducted. From the secondary sources, the literature review has been developed. Structural questions have prepared consists of 35 items for data collections. Five issues are related to demographic variables such as gender, age, occupation, education and monthly income. Twenty-eight questions are about sources of green awareness which influence consumers purchase green products. Thus section 2 is composed of awareness measures by using five point Likert scales (from $1=$ 'Strongly disagree' to $5=$ 'Strongly agree'), there is first question with five propositions which are linked to the environmental concern (environment betterment, consumer's responsibility, serious issue, contribute to saving my planet earth, avoid non green), the second question with three propositions which are linked to the knowledge ( have education, have learned, attended conference), the third question with three propositions which are linked to the eco-friendly products (benefits, past used, marketing offering), the fourth question with three propositions which are linked to the social media ( have learned from Facebook, twitter etc, social media, available information ), the fifth question with five propositions which are linked to promotional activities(ads with green themes \& message, labels green, better heath, creating awareness and enough to buy) and the sixth question with five propositions which are linked to reference groups ( friends \& colleagues, family pressure, friends ask, culture/region, celebrities)to create green products awareness. Seventh question Green products awareness consists of four statements (clearly and completely, satisfied, recommend, purchase green products in future).Two multiple items scale questions deal with the consumer green purchasing behaviour. Applying the convenience and judgemental sampling techniques, primary data is collected through the personal interview with 300 respondents. Cronbach's Alpha is 0.837 for 28 items of variables which suggest that the examination instrument is reliable to evaluate all hypotheses reliably and free from random error. Data collected from questionnaires are analysed by applying several statistical tools like mean, standard deviation and regression analysis by using SPSS 16.0.

\section{Results and Discussions}

\subsection{The Demographic Profile of Respondents}

Table 1 presents the different frequency and percentages of the demographic profile of respondents. Most of the respondents are males $(70.3 \%)$ while females are $29.7 \%$. It is observed that respondents are mostly in the age groups $18-25$ years old (59.3\%), known as young. Besides, young generation are highly concern about anything 
new to the society and react to different situation faster than any other age class. So this study considers maximum number of participants from this group. The second highest of respondents are in the age categories $26-40$ years $(21.7 \%)$. The third highest of respondents are in the age categories $41-55$ years $(15.7 \%)$, and minority of respondents are in the age categories 56 years above $(3.3 \%)$. These young people tend to have been more concerned about the green environment and influenced a purchasing decision. With regards to educational qualification, $38.3 \%$ of respondents are undergraduate, $31.3 \%$ of respondents are postgraduate, $27.7 \%$ of respondents are graduate, and $2.7 \%$ of the respondents are others. These most of respondents are undergraduate, and minorities of respondent are others. Also about employment status, the majority of respondents are students $(55.3 \%)$, the second highest of respondents are in-service $(23.7 \%)$, and the third highest of the respondents are own business (12.7\%). Lastly, the fourth highest of respondents are homemakers (5.7\%), the fifth highest of respondents are agriculture $(2.0 \%)$ and minority of respondents are others $(0.7 \%)$. It presented that respondents are the majority in the income level below 20,000(47.3\%), the second highest of respondents are income level $20,000-50,000(38.3 \%)$, the third highest of respondents are income level 50,000-80,000(11.7\%) and a minority of respondents are income level 80,000 above $(2.7 \%)$.

Table 1. The demographic profile of respondents

\begin{tabular}{|c|c|c|}
\hline & Frequency & Percentage \\
\hline \multicolumn{3}{|l|}{ Gender } \\
\hline Male & 211 & 70.3 \\
\hline Female & 89 & 29.7 \\
\hline \multicolumn{3}{|l|}{ Age } \\
\hline 18-25 Years & 178 & 59.3 \\
\hline $26-40$ Years & 65 & 21.7 \\
\hline 41-55 Years & 47 & 15.7 \\
\hline 56 Years + & 10 & 3.3 \\
\hline \multicolumn{3}{|c|}{ Education Qualification } \\
\hline Undergraduate & 115 & 38.3 \\
\hline Graduate & 83 & 27.7 \\
\hline Postgraduate & 94 & 31.5 \\
\hline Others & 8 & 2.7 \\
\hline \multicolumn{3}{|c|}{ Employment Status } \\
\hline In service & 71 & 23.7 \\
\hline Own business & 38 & 12.7 \\
\hline Agriculture & 6 & 2.0 \\
\hline Homemaker & 17 & 5.7 \\
\hline Student & 166 & 55.3 \\
\hline Others & 2 & 0.7 \\
\hline \multicolumn{3}{|l|}{ Monthly Income } \\
\hline Below 20,000 & 142 & 47.3 \\
\hline $20,000-50,000$ & 115 & 38.3 \\
\hline $50,000-80,000$ & 35 & 11.7 \\
\hline 80,0000 above & 8 & 2.7 \\
\hline
\end{tabular}

\subsection{Sources of Consumers Awareness}

Table 2 reveals a total picture of different sources of consumer awareness towards green products by expressing respondents' opinion on various issues related to creating awareness. Majority of respondents have agreed Promotional activities $(\mathrm{M}=3.67466$ \& $\mathrm{SD}=0.798378)$ become the most significant factors in sources of 
consumers green products awareness. Environmental concern $(\mathrm{M}=3.56266 \& \mathrm{SD}=0.862316)$ is the second essential factors in sources of consumer's green products awareness. Eco-friendly products $(\mathrm{M}=3.4834$ \& $\mathrm{SD}=0.9402667)$ become the third significant factors. Social media $(\mathrm{M}=3.3689 \& \mathrm{SD}=0.96213)$ is the fourth significant factors. Reference groups $(\mathrm{M}=3.206 \& \mathrm{SD}=0.929534)$ are the fifth significant factors in sources of consumer's green products awareness. Knowledge $(\mathrm{M}=3.01667 \& \mathrm{SD}=1.001687)$ is the less significant factors in sources of consumer's green products awareness.

Table 2. Descriptive statistics analysis

\begin{tabular}{|c|c|c|c|c|}
\hline S.No. & & & Mean & Std.Dev \\
\hline & Environmental Concern & & & \\
\hline 1. & Green product is environmental betterment & & 3.8400 & 0.67025 \\
\hline 2. & Environmental issues are consumer responsibility & & 3.6900 & 0.76322 \\
\hline 3. & Deterioration of the environment is a serious issue & & 3.7400 & 0.82137 \\
\hline 4. & Saving planet earth & & 3.7700 & 0.87921 \\
\hline \multirow[t]{3}{*}{5.} & Avoid buying nongreen & & 2.7733 & 1.17753 \\
\hline & & Average & 3.56266 & 0.862316 \\
\hline & Knowledge & & & \\
\hline 1. & Have education of environment $\&$ green products & & 3.2533 & 0.95158 \\
\hline 2. & Have learned of green products & & 3.0800 & 0.98157 \\
\hline \multirow[t]{3}{*}{3.} & Have attended conference/seminar & & 2.7167 & 1.11078 \\
\hline & & Average & 3.016667 & 1.001687 \\
\hline & Eco-Friendly Products & & & \\
\hline 1. & Benefits of green products & & 3.8767 & 0.75056 \\
\hline 2. & Past used of green products & & 3.4000 & 0.99833 \\
\hline \multirow[t]{3}{*}{3.} & Various marketing offering & & 3.1867 & 1.07191 \\
\hline & & Average & 3.4834 & 0.9402667 \\
\hline & Social Media & & & \\
\hline 1. & Have learned from Facebook, Twitter, YouTube, etc. & & 3.8000 & 0.78446 \\
\hline 2. & Social media aware of green products & & 3.4867 & 0.90511 \\
\hline \multirow[t]{3}{*}{3.} & Green products information are available & & 2.8200 & 1.19682 \\
\hline & & Average & 3.3689 & 0.96213 \\
\hline & Promotional Activities on Eco-friendly Products & & & \\
\hline 1. & Ads with green themes \&message about saving environment & & 3.5733 & 0.81661 \\
\hline 2. & Labels are good sources of green information & & 3.6733 & 0.75400 \\
\hline 3. & Green products are better for health as well as environment & & 3.6100 & 0.77884 \\
\hline 4. & Creating awareness about green products & & 3.5967 & 0.78061 \\
\hline \multirow[t]{3}{*}{5.} & Enough information to buy green products & & 3.9200 & 0.86183 \\
\hline & & Average & 3.67466 & 0.798378 \\
\hline & Reference Groups & & & \\
\hline 1. & Friends \&colleagues have informed & & 3.6067 & 0.80047 \\
\hline 2. & Pressure of family members to know & & 2.8533 & 0.96346 \\
\hline 3. & Friends ask foridea & & 3.4233 & 0.86793 \\
\hline 4. & Culture /region affect to green aware & & 2.7500 & 1.07300 \\
\hline \multirow[t]{2}{*}{5.} & Green aware for celebrities & & 3.3967 & 0.94284 \\
\hline & & Average & 3.206 & 0.929534 \\
\hline
\end{tabular}




\subsection{Green Products Awareness}

Table 3 depicts that majority of the respondents (43.0\%) Agree about the awareness of green products. Among rest of respondents ( $41.0 \%$ somewhat, $8.3 \%$ disagree, $4.7 \%$ strongly agree, and $2.3 \%$ strongly disagree) are level of awareness regarding green products. Hence most of the respondents are aware of green products. Moreover, $45.0 \%$ respondents agree that they are satisfied regarding green products. Also, $73.0 \%$ respondents agree to recommend friends, family, and others.

Table 3. Green product awareness

\begin{tabular}{|c|c|c|c|c|c|c|c|c|}
\hline & \multicolumn{2}{|c|}{$\begin{array}{c}\text { Green Product } \\
\text { Awareness }\end{array}$} & \multicolumn{2}{|c|}{$\begin{array}{c}\text { Satisfy Regarding Green } \\
\text { Products }\end{array}$} & \multicolumn{2}{|c|}{$\begin{array}{l}\text { Recommend Friends, Family } \\
\qquad \& \text { Others }\end{array}$} & \multicolumn{2}{|c|}{$\begin{array}{l}\text { Purchase in } \\
\text { Future }\end{array}$} \\
\hline & f & $\%$ & f & $\%$ & f & $\%$ & $\mathbf{f}$ & $\%$ \\
\hline Strongly Disagree & 7 & 2.3 & 6 & 2.0 & 2 & 0.7 & 2 & 0.7 \\
\hline Disagree & 25 & 8.3 & 14 & 4.7 & 4 & 1.3 & 3 & 1.0 \\
\hline Somewhat & 123 & 41.0 & 132 & 44.0 & 34 & 11.3 & 19 & 6.3 \\
\hline Agree & 131 & 43.0 & 135 & 45.0 & 219 & 73.0 & 195 & 65.0 \\
\hline Strongly Agree & 14 & 4.7 & 13 & 4.3 & 41 & 13.7 & 81 & 27.0 \\
\hline
\end{tabular}

\subsection{Purchasing Behaviour}

Table 3 presents that most of the respondents $(65.0 \%$ agree \& $27.0 \%$ strongly agree) will purchase green products in future. According to Table- $4,59 \%$ respondents buy green product regularly when they need, and over $60 \%$ respondents are interested in purchasing green product always and often. So consumers have positive attitudes towards green product purchase.

Table 4. Green buying

\begin{tabular}{lrr}
\hline & Frequency & Percentage \\
\hline Frequently Buy & & \\
Once a week & 16 & 5.3 \\
Once a Fornight & 11 & 3.7 \\
Once a Month & 49 & 16.3 \\
Once a Year & 47 & 15.7 \\
Regular when needed & 177 & 59.0 \\
Repeat Purchase in Future & & \\
Not At All & 19 & 6.3 \\
Sometimes & 91 & 30.3 \\
Often & 95 & 31.7 \\
Always & 95 & 31.7 \\
\hline
\end{tabular}

\subsection{Result of Regression Analysis}

4.5.1 Predict the Relationship between Factors and Consumers Green Awareness

Table 5 presents that correlation coefficient value $(\mathrm{R})$ is equal to 0.350 which recommends that there is a reasonable positive correlation between green products awareness and environmental concern, knowledge, eco-friendly products, social media, promotional activities on eco-friendly products, reference group. Moreover, coefficient of determinant $\left(\mathrm{R}^{2}\right)$ is 0.123 which indicate that due to independent factors (environmental concern, knowledge, eco-friendly products, social media, promotional activities on eco-friendly products and reference groups) dependent variable varies only $12.3 \%$. It implies that there is the impact of other factors on green products awareness. These aspects are expected to be discovered in upcoming study. 


\subsubsection{Confirm the Model Fitness}

Table 5 reveals that regression analysis is accomplished to recognise the relationship between environmental concern, knowledge, eco-friendly products, social media, promotional activities and reference group with their green products awareness. Six hypotheses are anticipated, and results are computed in Table 5 and demonstrated in Figure 2. F-value is 6.834 with a significant level 0.000 which is less than 0.01 and it assures model fitness for regression analysis.

\subsubsection{Factors Influencing Consumers' Green Products Awareness}

The outcomes in Table 6 and Figure 2 agree that consumer' environmental concerns don't significantly influence their green products awareness $(\beta 1=0.041 ; \mathrm{t}$-value $=0.619 ; p>0.05)$. Thus, $\mathrm{H} 1$ is not accepted and suggesting that customers' environmental concerns don't influence their green products awareness (Suki, 2013). This study is dissimilar to the conclusions of Gan et al. (2008), where the study has found a relationshipbetween environmental concern and awareness. Next, H2 substantiate that consumers 'knowledge don't significantly influence their green products awareness $(\beta 2=0.076$; t-value $=1.154 ; p>0.05)$. Therefore, $\mathrm{H} 2$ is not accepted. Consumers' knowledge has no effects on their green product awareness. Next, H3 substantiates that eco-friendly products do not significantly influence their green products awareness $(\beta 3=0.019$; t-value $=0.256 ; p>0.05)$. So, $\mathrm{H} 3$ is not accepted. Eco-friendly products have no effects on their green product awareness. The result of the study presented that eco-friendly products are not influenced consumers green awareness (Souza'D et al., 2006; Suki, 2013).Next, H4 substantiates that social media don't significantly influence their green products awareness $(\beta 4=0.046$; $\mathrm{t}$-value $=0.666 ; p>0.05)$. As a result, $\mathrm{H} 4$ is also not accepted. Social media has no effects on consumers green products awareness.

Table 5. Predict the relationship between factors and consumers green awareness \& Confirm the model fitness

\begin{tabular}{lllcccc}
\hline \multicolumn{7}{c}{ ANOVA } \\
\hline Model & & Sum of Squares & Df & Mean Square & F & Sig. \\
\hline \multicolumn{1}{c}{1} & Regression & 23.571 & 6 & 3.929 & $\mathbf{6 . 8 3 4}$ & $\mathbf{. 0 0 0}$ \\
& Residual & 168.429 & 293 & .575 & & \\
& Total & 192.000 & 299 & & & \\
\hline R & & & & 0.350 \\
R Square & & & & 0.123 \\
Adjusted R Square & & & & 0.105 \\
Std.Error of Estimate & & & & 0.75818 \\
\hline
\end{tabular}

The outcomes of regression analysis for $\mathrm{H} 5$ as presents in Table 6 and Figure 2 indicate that promotional activities on eco-friendly products as the critical factor, which significantly affects consumers green products awareness $(\beta 5=0.161 ; \mathrm{t}$-value $=2.618 ; p<0.05)$. Thus, there is a significant relation between promotional activities on eco-friendly products and consumers' green products awareness. The results for H6 as shown in Table 6 and Figure 2 indicate that reference groups as another critical factor, which significantly affects consumers green product awareness $(\beta 6=0.167$; $\mathrm{t}$-value $=2.756 ; p<0.05)$. Thus, there is a significant relation between reference groups and green products awareness. 
Table 6. Factors influencing consumers' green products awareness

\begin{tabular}{|c|c|c|c|c|c|}
\hline \multirow[t]{2}{*}{ Variable } & \multicolumn{2}{|c|}{ Unstandardized Coefficients } & \multirow{2}{*}{$\begin{array}{l}\text { Standardized Coefficients } \\
\text { Beta }\end{array}$} & \multirow[t]{2}{*}{$\mathrm{T}$} & \multirow[t]{2}{*}{ Sig. } \\
\hline & B & Std. Error & & & \\
\hline Constant & 1.021 & .404 & & 2.527 & .012 \\
\hline Environmental Concern & .059 & .095 & .041 & .619 & .536 \\
\hline Knowledge & .081 & .070 & .076 & 1.154 & .249 \\
\hline Eco-friendly Product & .024 & .093 & .019 & .256 & .798 \\
\hline Social Media & .051 & .077 & .046 & .666 & .506 \\
\hline Promotional Activities & .250 & .095 & .161 & 2.618 & .009 \\
\hline Reference Groups & .235 & .085 & .167 & 2.756 & .006 \\
\hline
\end{tabular}

\subsubsection{Predict the Relationship between Green Awareness and Purchase Decision}

Table 7 exposes that the value of correlation coefficient (R) is 0.268 and recommends a reasonable positive correlation between green products awareness \& green purchase decision. However, only $7.2 \%$ (R-square values of 0.072 ) difference in the green purchase decision is counted because of green products awareness effect. So it infers other factors influence on the green purchase decision which are not observed.

\subsubsection{Confirm the Model Fitness}

Regression analysis is executed to identify the relationship between green products awareness and purchase decision. Last hypothesis is projected, and results are represented in Table 7 and shown in Figure 2. F-value is 23.107 with a significant level 0.000 which is less than 0.01 and it assures model fitness for regression analysis.

Table 7. Predict the relationship between green awareness and purchase decision \& confirm the model fitness

\begin{tabular}{llllllc}
\hline \multicolumn{7}{c}{ ANOVA } \\
\hline Model & & Sum of Squares & Df & Mean Square & F & Sig. \\
\hline 1 & Regression & 8.755 & 1 & 7.522 & $\mathbf{2 3 . 1 0 7}$ & $\mathbf{. 0 0 0}$ \\
& Residual & 112.911 & 298 & .340 & & \\
& Total & 121.667 & 299 & & & \\
\hline R & & & & 0.268 \\
R Square & & & & 0.072 \\
Adjusted R Square & & & & 0.069 \\
Std. Error of Estimate & & & & 0.61555 \\
\hline
\end{tabular}

\subsubsection{Consumers' Green Awareness Influences the Green Purchase Decision}

The results of multiple regression analysis for $\mathrm{H} 7$ as presents in Table 8and Figure 2 indicate green products awareness as the essential factor, which significantly affects their green purchase decision $(\beta 11=0.268$; $\mathrm{t}$-value $=$ 4.807; $p<0.05$ ).Thus, the significant relation between green products awareness and green purchase decision. Suki (2013) also found that there is a significant relation between green products awareness and green purchase decision.

Table 8. Consumers' green awareness influence the green purchase decision

\begin{tabular}{|c|c|c|c|c|c|}
\hline \multirow[t]{2}{*}{ Variable } & \multicolumn{2}{|c|}{ Unstandardized Coefficients } & \multirow{2}{*}{$\begin{array}{l}\text { Standardized Coefficients } \\
\text { Beta }\end{array}$} & \multirow[t]{2}{*}{$\mathrm{T}$} & \multirow[t]{2}{*}{ Sig. } \\
\hline & $\mathrm{B}$ & Std. Error & & & \\
\hline Constant & 3.441 & .155 & & 22.174 & .000 \\
\hline Green product awareness & .214 & .044 & .268 & 4.807 & .000 \\
\hline
\end{tabular}




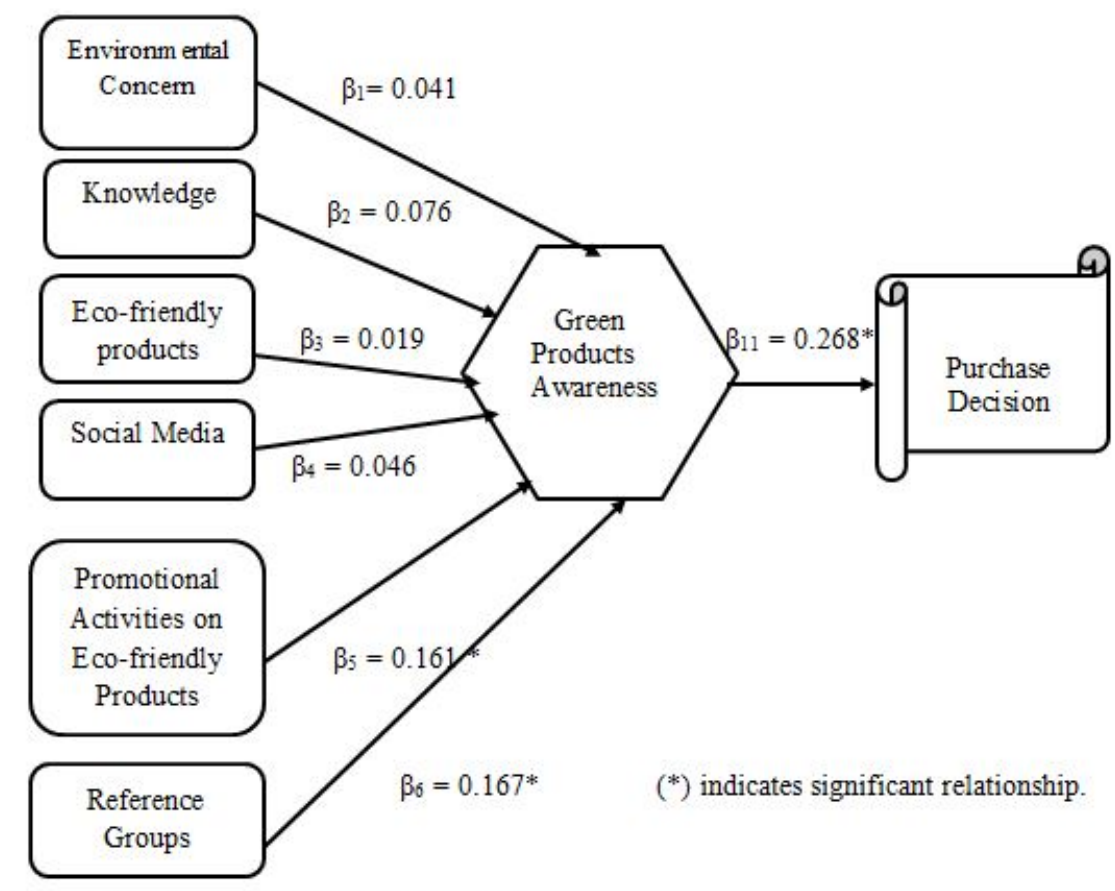

Figure 2: The Results of the Full Model

Figure 2. The results of the full model

\section{Conclusion and Implications}

The study has been conducted with an objective to explore the sources of consumers' awareness toward green products and its impact on purchasing decision. Different green products source is important tools to guide the consumers' green products awareness. This research examines environmental concern, knowledge, eco-friendly products, social media, promotional activities on eco-friendly products and reference groups influence consumers to green products awareness and its impact on their purchasing decision. From the results of regression analysis, the research is found that promotional activities on eco-friendly products and reference groups significantly affect consumers' green products awareness. Promotional activities on eco-friendly products are the most influential factor that has positively influenced their green products awareness. Reference groups should be informed to encourage green products awareness. This study indicates that reference groups as the critical factor, which significantly affects their green products awareness. The study is revealed that consumers' environmental concerns do not affect the green products awareness. The outcomes of the study found that consumers' environmental concerns are not influenced consumers green awareness (Suki, 2013). The study is in dissimilar to the results of Gan et al. (2008), which found that consumers are concerned about the environment. Respondents' knowledge \& Social media have no effects on consumers green product awareness. Eco-friendly products are not affected their green product awareness. The result of the study presented that eco-friendly products are not influenced consumers green awareness (Souza'D et al., 2006; Suki, 2013). As the consumers are getting more awareness about green products, it influences purchasing decision. Most of the respondents are aware of green products. This study reveals that green products awareness as the crucial factor, which significantly affects their green purchase decision. Thus, there is a significant relation between green products awareness and green purchase decision. The outcomes of the study depicted that consumers green products awareness are influenced their green purchase decision (Suki, 2013).

The outcomes of this study can be beneficial for both researchers and practitioners. For researchers, it provides guidelines for understanding awareness patterns, level, and their relative importance. Alone with literature for future research, this study indicates ways to find out more profound factors which affect awareness of consumers. Besides, this study provides practical guidance and relevant suggestions to the business people and marketing experts to promote the strategies for enhancing green product awareness as environmental issues are opportunities to generate consumer demand. 


\section{Limitation and Further Research}

The study is restricted in Bangladesh only, and the result may not apply to other places. This data may not be the real representative of overall Bangladeshi consumers' view because of sample size. Further research is instructed to develop the generalizability of the sampling by extending the sample size. The study is found few influences of the independent variable. So there may be some other variable which may influence green products awareness. Those factors are left for future research.

\section{References}

American Marketing Association. (n.d.). Retrieved March 30, 2017, from http://www.marketingpower.com/_layouts/Dictionary.aspx?dLetter=G

Barr, S., \& Gilg, A. (2006). Sustainable Lifestyles: Framing Environmental Action in and Around the Home. Geoforum, 37, 906-909. https://doi.org/10.1016/j.geoforum.2006.05.002

Blackwell, R., D’Souza, C., Taghian, M., Miniard, P., \& Engel, J. (2006). Consumer Behavior: An Asia Pacific Approach. engage Learning Australia Pty Limited, South Melbourne.

Borin, N., Lindsey-Mullikin, J., \& Krishnan, R. (2013). An Analysis of Consumer Reactions to Green Strategies.Journal of Product \& Brand Management, 22(2), 118-128. https://doi.org/10.1108/10610421311320997

Carlson, \& George, M. Z. (1995). Green Advertising and the Reluctant Consumer.Journal of Advertising, 24(2), 1-6. https://doi.org/10.1080/00913367.1995.10673471

Chang, C. (2011). Feeling Ambivalent about Going Green - Implication for Green Advertising Processing.Journal of Advertising, 40(4), 19-319. https://doi.org/10.2753/JOA0091-3367400402

Chartrand, T. L. (2005). The Role of Conscious Awareness in Consumer Behavior. Journal of Consumer Psychology, 15(3), 203-210. https://doi.org/10.1207/s15327663jcp1503_4

Cherian, J., \& Jacob, J. (2012). Green Marketing: A Study of Consumers 'Attitude towards $\begin{array}{llll}\text { Environment-Friendly } \quad \text { Products.Asian } & \text { Social } & \text { Science, } & \text { 8(12), }\end{array}$ https://doi.org/10.5539/ass.v8n12p117

Cohen, M. R. (1973). Environmental Information Versus Environment Attitudes. Journal of Environmental Education, 5(2), 5-8. https://doi.org/10.1080/00958964.1973.10801804

Delafrooz, N., Taleghani, M., \& Nouri, B. (2014). Effect of Green Marketing on Consumer Purchasing Behavior.Science Connect. https://doi.org/10.5339/connect.2014.5

Desai, P. N. (2015). A Study of Consumer Awareness: Towards Eco-Friendly Buildings in Pune City. International Journal of Business Quantitative Economics and Applied Management Research, 1(8), 15-23.

Dommeyer, C. J., \& Gross, B. L. (2009). What Consumers Know and What They do: An Investigation of Consumer Knowledge, Awareness, and Use of Privacy Protection Strategies.Journal of Interactive Marketing, 17(2), 34-51. https://doi.org/10.1002/dir.10053

Donoghue, S., \& De Klerk, M. (2009). The Right to Be Heard and to Be Understood: A Conceptual Framework for Consumer Protection in Emerging Economies.International Journal of Consumer Studies, 33(4), 456-467. https://doi.org/10.1111/j.1470-6431.2009.00773.x

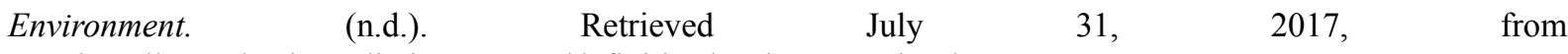
http://www.businessdictionary.com/definition/environment.html

Florenthal, B., \& Arling, P. (2011). Do Green Lifestyle Consumers Appreciate Low Involvement Green Products. Marketing Management Journal, 21(2), 35-45.

Forkink, A. (2010). Perception, Awareness, and Acceptance of Green Kitchen Cleaners: Go Green Market Research.Online report. Retrieved April23, 2017, from http://m.greenbook.org/marketing-research/green kitchen-cleaners/

Gan, C., Wee, H. Y., Ozanne, L., \& Kao, T. (2008). Consumers Purchasing Behavior toward Green Products in New Zealand. Innovative Marketing, 4(1), 93-102.

Ginsberg, J. M., \& Bloom, P. N. (2004). Choosing the Right Green Marketing Strategy, Massachusetts Institute of Technology (MIT).Sloan Management Review, (15), 79-84.

Glegg, G., Richards, J., Heard, J., \& Dawson, J. (2005). Barriers to Green Buying: Household Chemicals. A 
Report for the Clean Water Initiative. Working paper, Marine and Coastal Policy Research Group, University of Plymouth, Plymouth, January.

Gupta, S., \& Ogden, D. T. (2009). To buy or not to buy? A social Dilemma perspective on Green Buying. Journal of Consumer Marketing, 26(6), 376-391. https://doi.org/10.1108/07363760910988201

Hartlieb, S., \& Jones, B. (2009). Humanizing business through ethical labeling: progress and paradoxes in the UK.Journal of Business Ethics, 88(3), 583-600. https://doi.org/10.1007/s10551-009-0125-x

Hasan, Z., \& Ali, N. A. (2015). The Impact of Green Marketing Strategy on the Firm's Performance in Malaysia. Procedia- Social and Behavioral Sciences, 172(27), 463-470. https://doi.org/10.1016/j.sbspro.2015.01.382

Kotler, P., \& Armstrong, G. (2009). Principles of Marketing. Prentice Hall, New Jersey.

Kotler, P., Keller, K., Brady, M., Goodman, M., \& Hansen, T. (2009). Marketing Management. Pearson, London.

Kumar, S., Garg, R., \& Makkar, A. (2012). Consumer Awareness and Perception towards Green Products: A Study of Youngsters in India.International Journal of Marketing\& Business Communication, 1(4), 35-43.

Laroche, M., Bergeron, J., \& Babaro, F. G. (2001). Targeting consumers who are willing to pay more for environmentally friendly products. Journal of Consumer Marketing, 18(6), 503-520. https://doi.org/10.1108/EUM0000000006155

Luchs, Michael, G., Naylor, R. W., Irwin, R. J., \& Raghunathan, R. (2010). The Sustainability Liability: Potential Negative Effects of Ethicality on Product Preference.Journal of Marketing, 74(5), 18-31. https://doi.org/10.1509/jmkg.74.5.18

Luzio, J. P. P., \& Lemke, F. (2013). Exploring Green Consumers 'Product Demands and Consumption Processes.European Business Review, 25(3), 281-300. https://doi.org/10.1108/09555341311314825

Malhotra, N., \& Dash, S. (2014). Marketing Research. Pearson, India.

Mandese, J. (1991). New Study Finds Green Confusion. Advertising Age, 62(45), 1.

Marwick, N., \& Fill, C. (1997). Towards a Framework for Managing Corporate Identity.European Journal of Marketing, 31(5-6), 396-409. https://doi.org/10.1108/03090569710167619

Mayfield, T. D. (2008). What is social media? Retrieved August 1, 2017, from http://www.iCrossing. Com/ebooks/What_is_Social_Media_Crossing_ebook

Mcdonald, E., \& Sharp, B. (2003). Management Perceptions of the Importance of Brand Awareness as an Indication of Advertising Effectiveness.Marketing Bulletin. Retrieved July 30, 2017, from http://www.marketing bulletin.massey.ac.nz

McEachern, M., \& Warnaby, G. (2008). Exploring the Relationship between Consumer Knowledge and Purchase Behavior of Value-Based Labels.International Journal of Consumer Studies, 32(5), 414-426. https://doi.org/10.1111/j.1470-6431.2008.00712.x

Mohammadian, M., \& Mohammadreza, M. (2012). Identify the Success Factors of Social Media (Marketing Perspective). International Journal of Business and Management, 4(2), 58-66.

Moser, A. K. (2015). Thinking Green, Buying Green? Drivers of Pro-Environmental Purchasing Behavior. Journal of Consumer Marketing, 32(3), 167-175. https://doi.org/10.1108/JCM-10-2014-1179

Mowen, J. C., \& Minor, M. (2000). Consumer Behavior. Prentice Hall, New Jersey.

Murphy, P. E., Kangun, N., \& Locander, W. B. (1978). Environmentally Concerned Consumers - Racial Variations.Journal of Marketing, 42, 61-66. https://doi.org/10.2307/1250087

Ottman, J. A. (1993). Green Marketing: Opportunity for Innovation. McGraw Hill, NT Business Books, Chicago.

Polonsky, M. J. (1994). An Introduction to Green Marketing. Electronic Green Journal, 1(2). Retrieved June 30, 2017, from http://escholarship.org/uc/item/49n325b7

Prakash, A. (2002). Green Marketing, Public Policy and Managerial Strategies.Business Strategy \& the Environment, 11(5), 285-297. https://doi.org/10.1002/bse.338

Raska, D. (2012). When is Going Green Good for Company Image? Emerald Management Research Review, 35(3/4), 326-347. https://doi.org/10.1108/01409171211210190

Rather, R. A., \& Rajendran. (2014). A Study on Consumer Awareness of Green Products and its Impact on Green 
Buying Behavior. International Journal of Research, 1(8), 1483-1493.

Ritter, Á. M., Borchardt, M., Vaccaro, G. L. R., Pereira, G. M., \& Almeida, F. (2015). Motivations for Promoting the Consumption of Green Products in an Emerging country: Exploring Attitudes of Brazilian Consumers. Journal of Cleaner Production, 106(1), 507-520. https://doi.org/10.1016/j.jclepro.2014.11.066

Schlegemich, B., Bohlen, M. G., \& Diamantopoulos, A. (1996). The Link between Green Purchasing Decisions and Measures of Environmental consciousness.European Journal of Marketing, 30(5), 35-55. https://doi.org/10.1108/03090569610118740

Shabani, N., Ashoori, M., Taghinejad, M., Beyrami, H., \& Fekri, M. N. (2013). The Study of Green Consumers' Characteristics and Available Green Sectors in the Market.International Research Journal of Applied and Basic Sciences, 4(7), 1880-1883.

Sharma, P. (2010). Green Marketing in India: Emerging Opportunities and Challenges.Journal of Engineering, Science and Management Education, 3, 9-14.

Shrum, L. J., John, M. A., \& Tina, L. M. (1995). Buyer Characteristics of the Green Consumer and Their Implications for Advertising Strategy.Journal of Advertising, 24(2), 71-82. https://doi.org/10.1080/00913367.1995.10673477

Shruti, P. M. (2014). Awareness of Green Marketing and Its Influence on Buying Behavior of Consumers: Special Reference to Madhya.AIMA Journal of Management \& Research, 8(1/4). Retrieved April 30, 2017, from http://apps.aima.in/ejournalnew/articlespdf/3_dr_shruti_p_maheshwari.pdf

Smith, A. (2009). The Wealth of Nation- A Landmark Classic by Adam Smith. Thrifty Books,Blacksburg.

Solomon, M. R. (2006). Consumer Behavior: Buying, Having, and Being. Pearson Education.

Souza'D, C., Taghian, M., Lamb, P., \& Peretiatkos, R. (2006). Green products and Corporate Strategy: An Empirical Investigation. Society and Business Revie, 1(2), 144-157. https://doi.org/10.1108/17465680610669825

Srinivas, A. (2015). Consumer Awareness and Attitude towards Environmental Products. International Journal of Advanced Scientific Technologies, Engineering and Management Sciences, 1(2), 13-16.

Suki, M. N. (2013). Green Awareness Effects on Consumer Purchasing Decision. Penerbit, 9(2), 49-62.

Tiwari, S., Tripathi, D. M., Srivastava, U., \& Yadav, P. K. (2011). Green Marketing - Emerging Dimensions. Journal of Business Excellence, 2(1), 18-23.

Triantafillidou, A., \& Siomkos, G. (2014). Consumption experience outcomes: satisfaction, nostalgia intensity, word-of-mouth communication and behavioural intentions.Journal of Consumer Marketing, 31(6/7), 526-540. https://doi.org/10.1108/JCM-05-2014-0982

Wahid, N. A., \& Rahbor, E. (2011). Investigation of Green Marketing Tools Effect on Consumer's Purchase Behavior.Emerald Business Strategy, 12(2), 73-83.

Yazdanifard, R., \& Yan, Y. K. (2014). The Concept of Green Marketing and Green Product Development on Consumer Buying Approach.Global Journal of Commerce \& Management Perspective, 3(2), 33-38.

Yeonshin, K., \& Sejung, M. C. (2005). Antecedents of Green Purchase Behavior: An Examination of Collectivism, Environmental Concern, and PCE. NA-Advance in consumer research, 32, 592-599.

Young, W., Hwang, K., McDonald, S., \& Oates, C. J. (2010). Sustainable Consumption: Green Consumer Behaviour When Purchasing Products.Sustainable Development, 18(1), 20-31.

\section{Copyrights}

Copyright for this article is retained by the author(s), with first publication rights granted to the journal.

This is an open-access article distributed under the terms and conditions of the Creative Commons Attribution license (http://creativecommons.org/licenses/by/4.0/). 